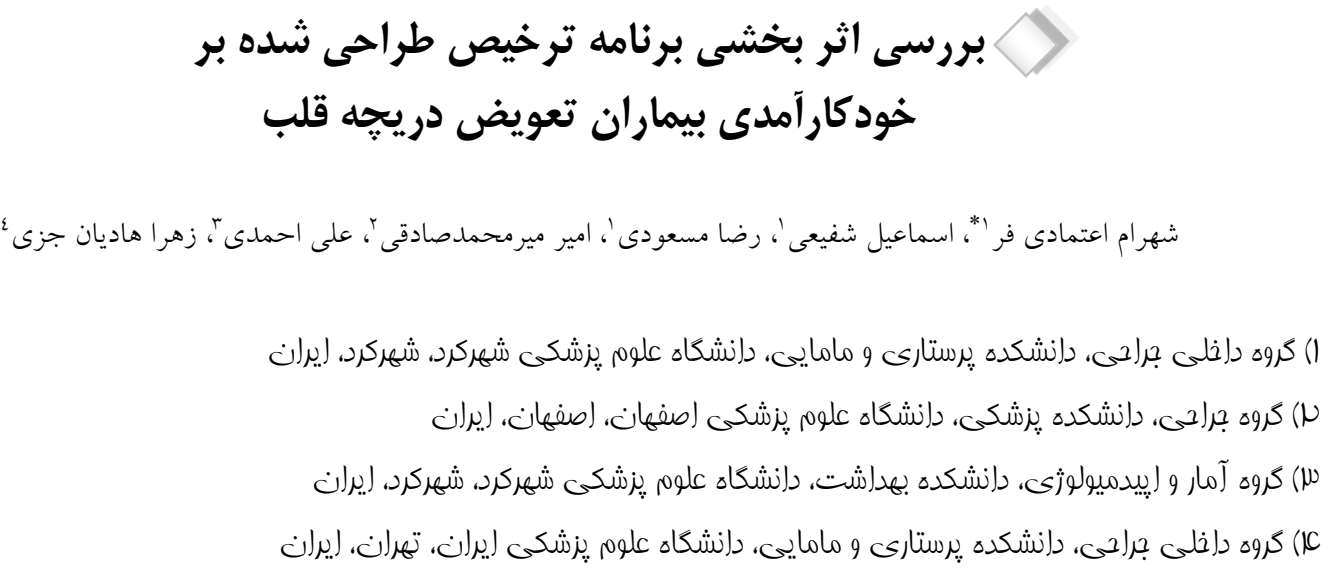

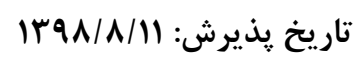

تاريخ دريافت: r/

\begin{abstract}
جكيده

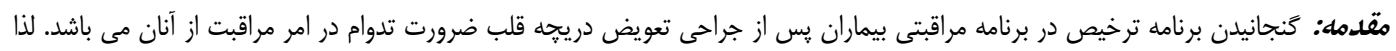

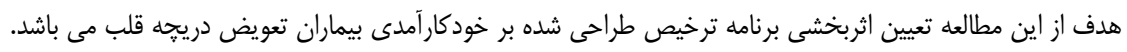

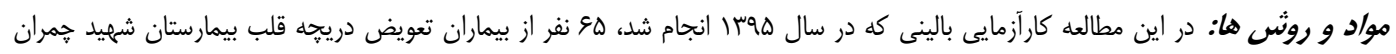

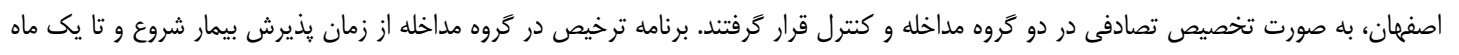

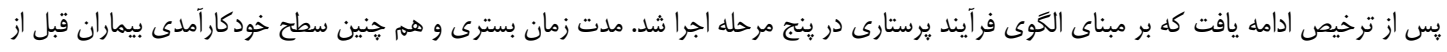

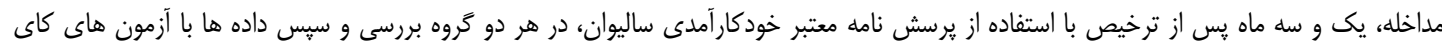

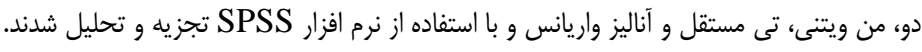

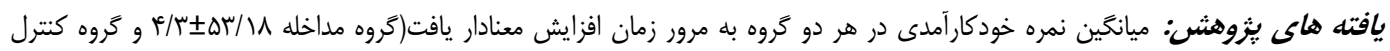

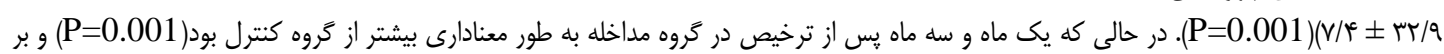

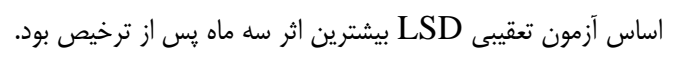

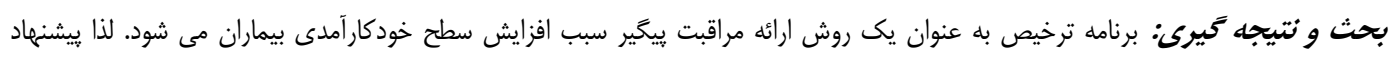

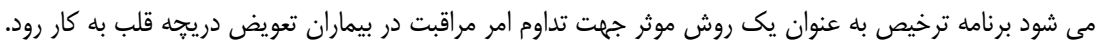
وازه هاى كليدى: برنامه ترخيص، خودكار آمدى، تعويض دريجه قلب

* نويسنده مسئول: گروه داخلى جراحى، دانشكده برستارى و مامايى، دانشكاه علوم يزشكى شهركرد، شهركرد، ايران Email: etemadifar@nm.mui.ac.ir

Copyright (C) 2019 Journal of Ilam University of Medical Science. This is an open-access article distributed under the terms of the Creative Commons Attribution international 4.0 International License (https://creativecommons.org/licenses/by-nc/4.0/) which permits copy and redistribute the material, in any medium or format, provided the original work is properly cited. 
در سال I9VV توسط آلبرت بندورا تعريف شد و از نظر

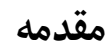
وى خودكارآمدى عاملى اساسى جهت تداوم تغيير رفتار

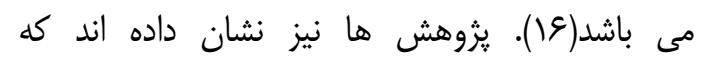
باورهاى خودكارآمدى باعث افزايش انخَيزه بيشرفت،

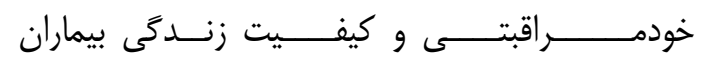

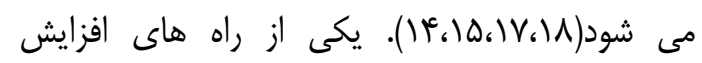

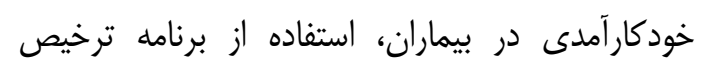

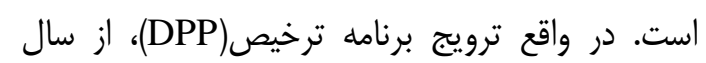

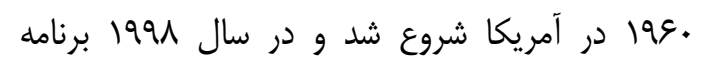
ترخيص به يك مداخله يرستارى مهم تبديل و به به ديه

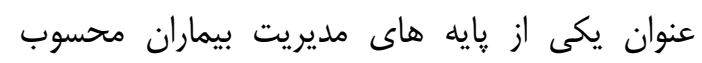

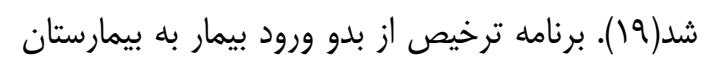

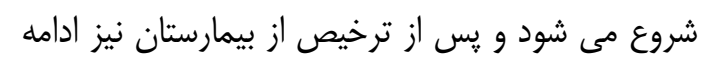

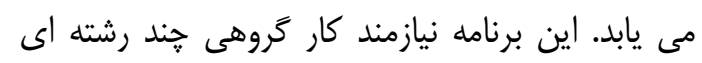

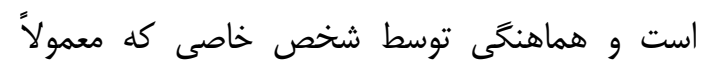

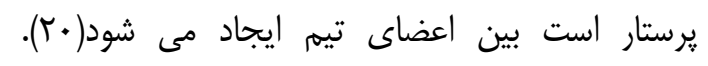

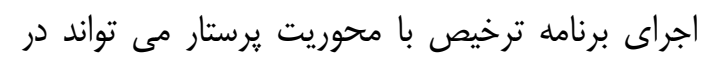

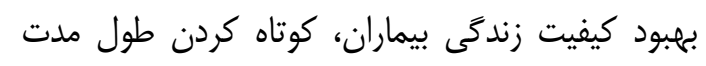

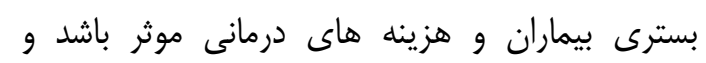

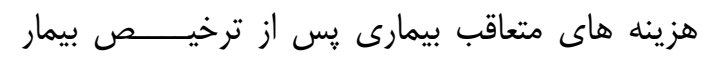

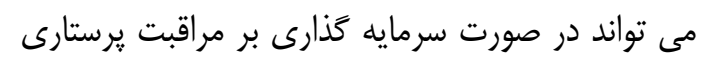

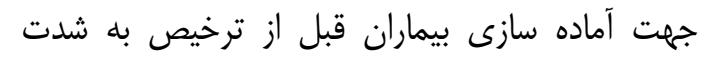

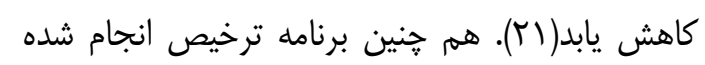

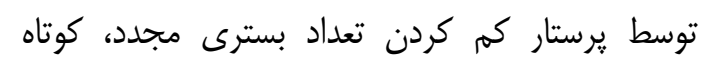

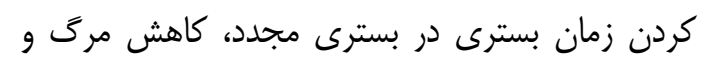

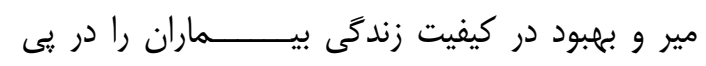

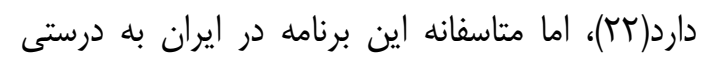
انجام نمى شود(س (ب).

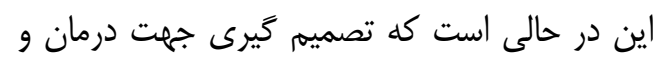

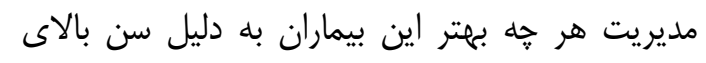

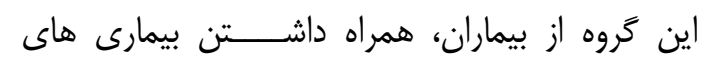

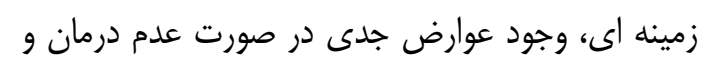

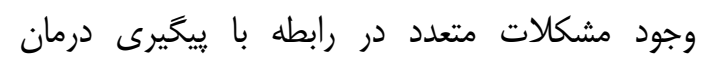

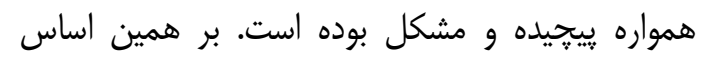

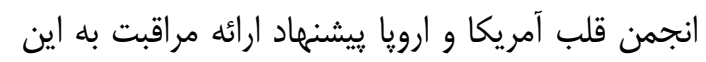

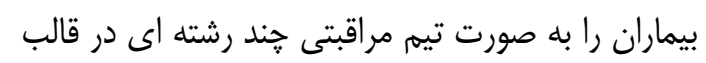

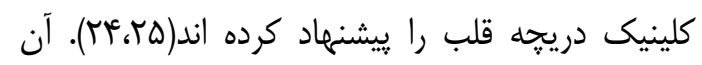

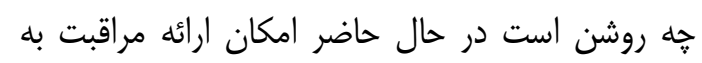

بيمارى هاى قلبى-عروقى عامل اصلى مرگ و مير

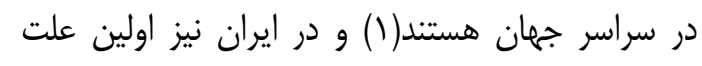

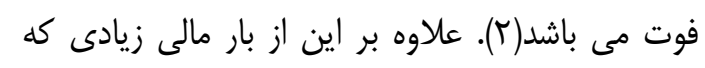
بيمارى هاى قلبى به سيسته بهداشتى تحميل مى كلى كنند

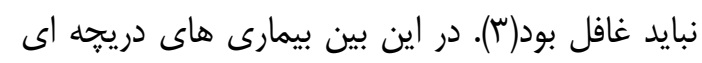

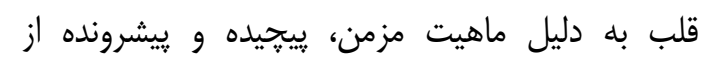

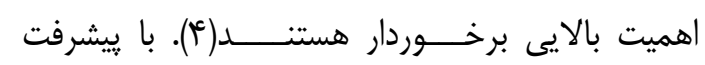

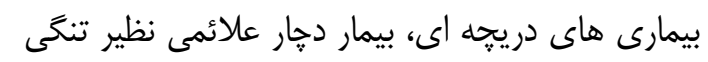

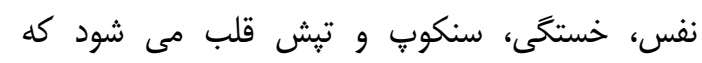

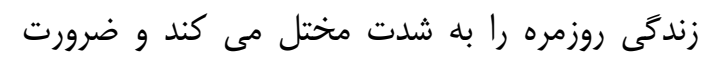

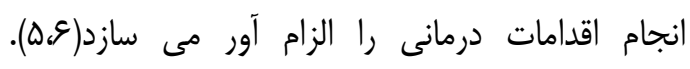
جراحى تعويض دريجه قلب به عنوان خط آخر آنر درمان

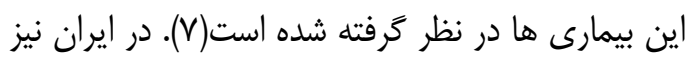

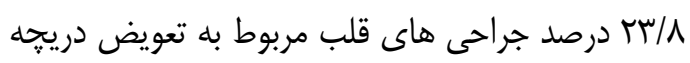

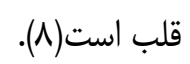

اكثر بيماران يس إز تعويض دريجه قلب از ضعف و

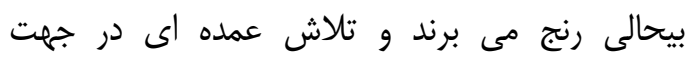

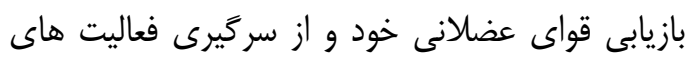

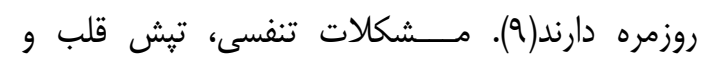

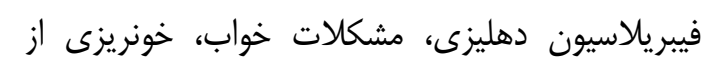
نقاط مختلف بدن، تغيير در فعاليت روزانه، خطر بروز دئل

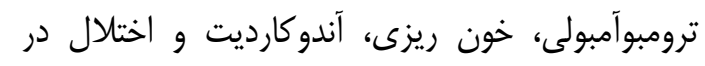

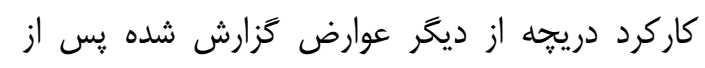

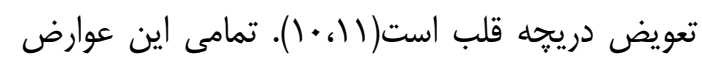

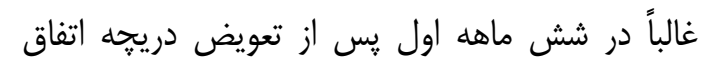

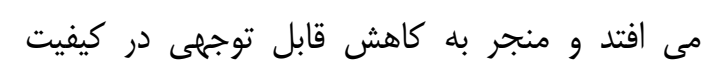

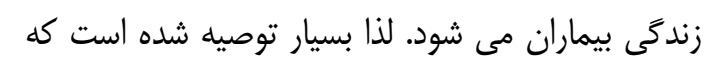

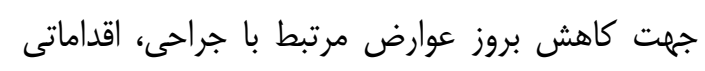

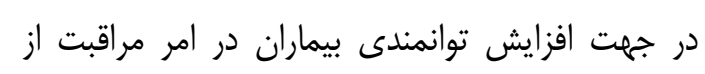

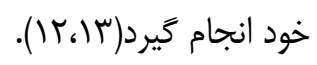
رفتارهاى خود مراقبتى شامل اقداماتى نظير كنترل علائم بيمارى، يذيرش رزيم درمانى، حفظ شيوه زندكى خدى

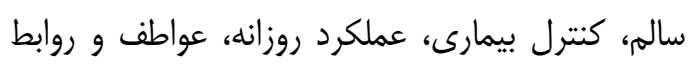

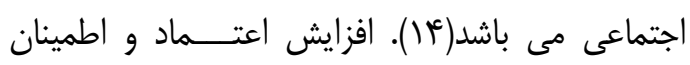

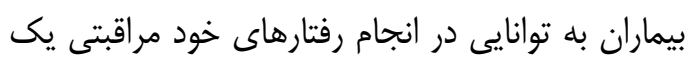
عامل اساسى در خودمديريتى اين بيمارى است كه

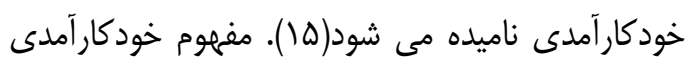


קمران اصفهان در سال هوسا انجام شد. جامعه يزوهش كليه بيماران تعويض دريجه قلب در بيمارستان شهيد קمران اصفهان بودند. معيارهاى ورود به مطالعه

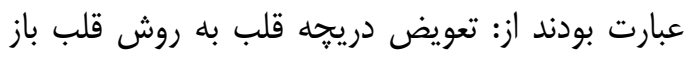
باشد، بيمار و همراه اصلى وى، سواد خواندن داشته باشد، جراحى قلب انتخابى باشد، بيمار اولين بار باشد كه تحت عمل جراحى قلب باز قرار مى گيرد، مشكل

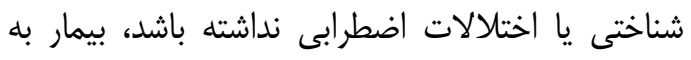

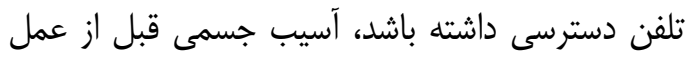

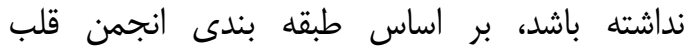

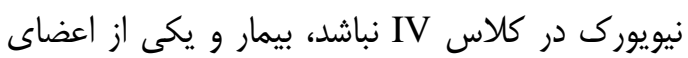

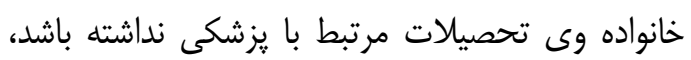

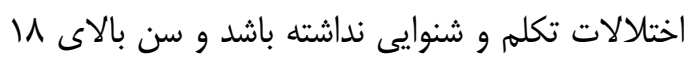

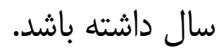
معيارهاى خروج از مطالعه شامل: بيمار از ادامه

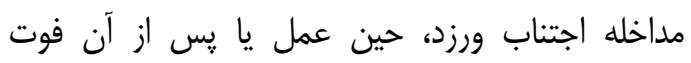
نمايد و قادر به تكميل يرسش نامه نباب ورنه حناشد.

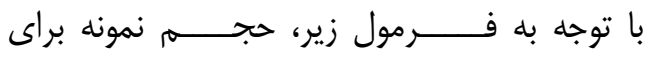

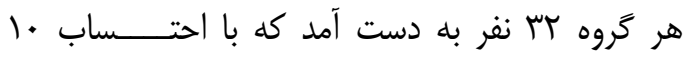

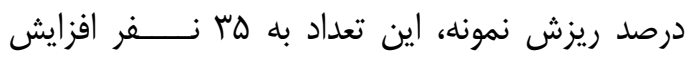

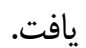

اين بيماران در قالب كلينيك دريجه قلب در كشور ما وجود ندارد، هرا كه مستلزم فراهم سازى بسترهاى

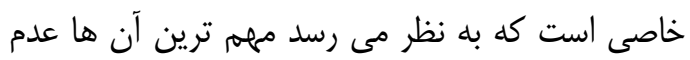

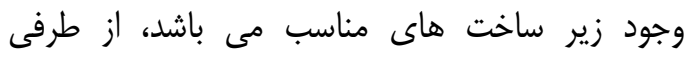

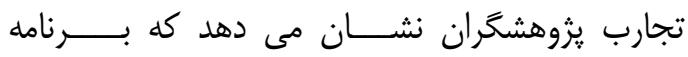
سازمان دهى شده و ييگر ديخرى نيز، جهت مديريت و

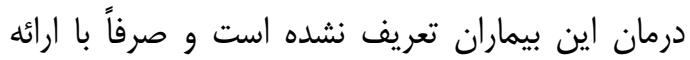
يك يمفلت آموزشى بدون در نظر گرفتن شر ايط بيمار و

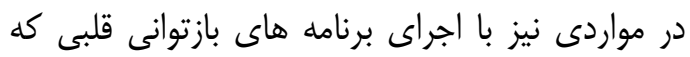

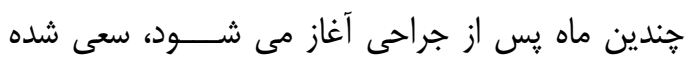

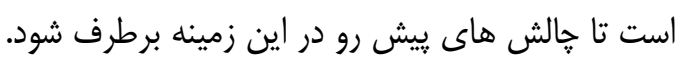

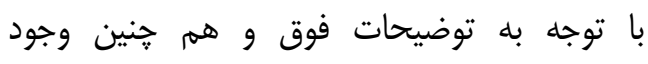

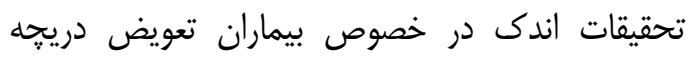

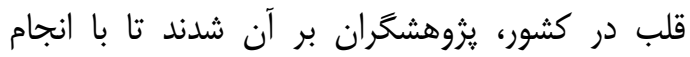
تروهشى تحت عنوان "ابررسى ميزان اثربخشى برنامه

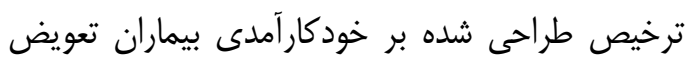

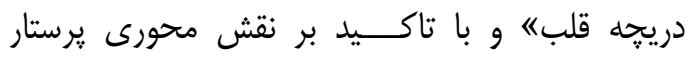

جالش هاى موجود در اين زمينه را برطرف نمايند.

\section{مواد و روش ها هان موجن}

مطالعه حاضر يك كارآزمايى بالينى دو كَروهى و سه مرحله ایى است كه در مركز آموزشى -درمانى شهيد باريد

$$
n=\frac{2 S^{2}\left(Z_{1}+Z_{2}\right)^{2}}{d^{2}}=\frac{2 S^{2}(1.96+0.84)^{2}}{0.49 S^{2}}=32
$$

و مشاهده يرونده بيمار و ابزار خــــردآورى داده ها، يرسش نامه بود كه شامل فرم هاى ثبت اطلاعنات

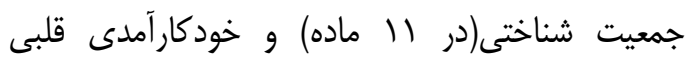

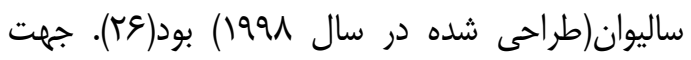

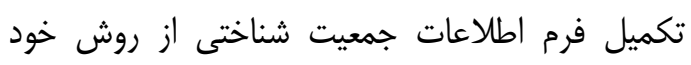
ززارش دهى، مصاحبه(در صورت عدم توانايى بيمار به الهات

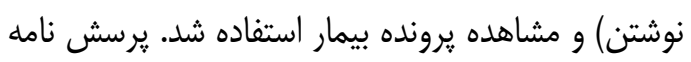

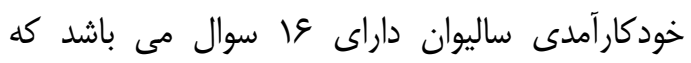

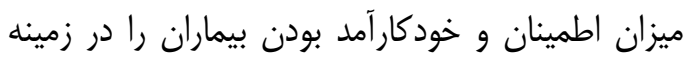
رعايت مراقبت هاى عمومى، كنترل علائم بيمارى و وردان

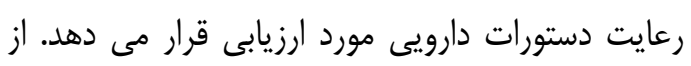

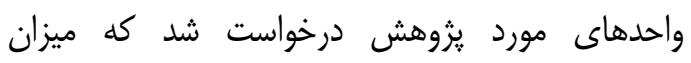
موافقت خود را نسبت به هر يك از سوالات، مطابق با بان طيف ليكرتى ع امتيازى از خيلى زياد تا اصلاً اعلام

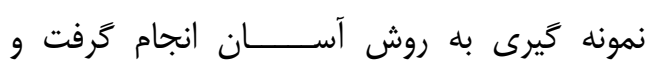

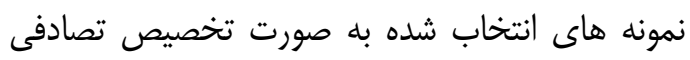

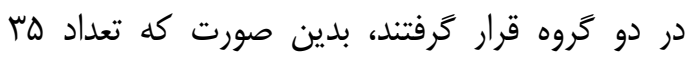

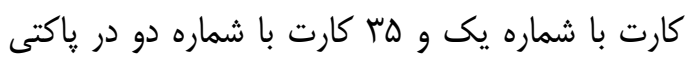

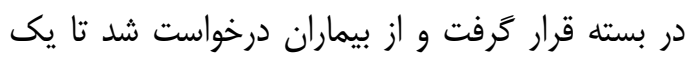

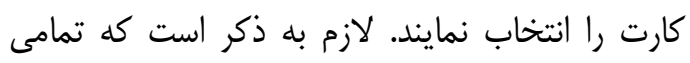

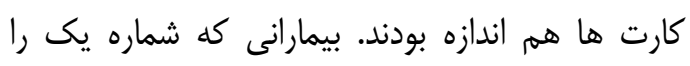

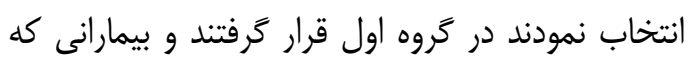
شماره دو به آن ها اختصاص يافت در كَروه دور دوم قرار

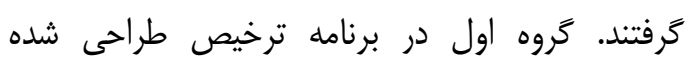

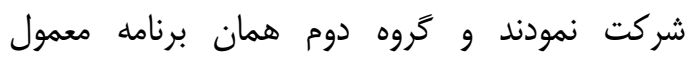
بيمارستان كه شامل بروشور آموزشى حاوى نهون نكات

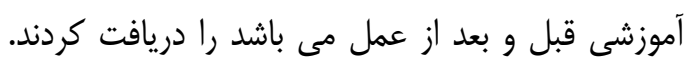
روش هاى كردآورى اطلاعات در اين مطالعه، مصاحبه 
قرار كرفت تا نظرات اصلاحى و ييشنهادى خود را ارائه

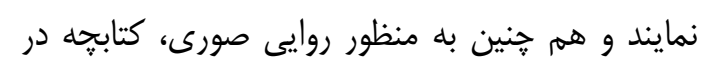

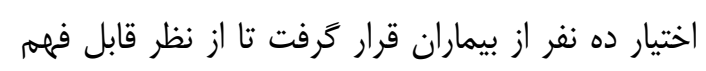

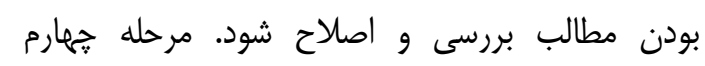
(اجراى برنامه ترخيص): مداخله شامل دو نوع مداخله

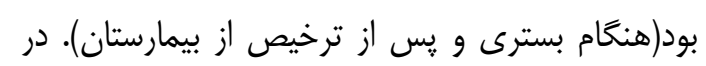

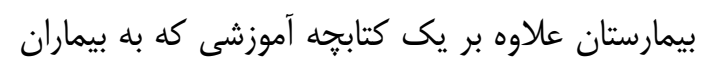

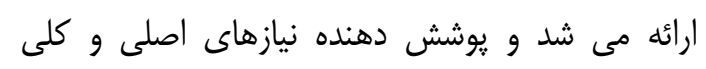

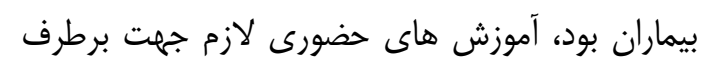

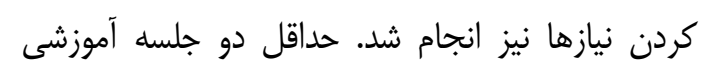

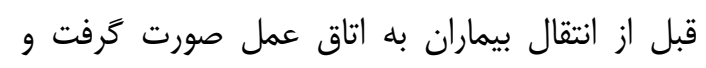

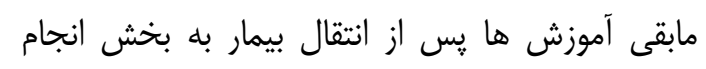

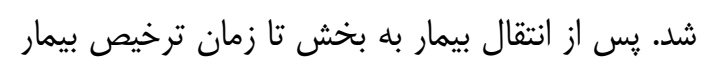

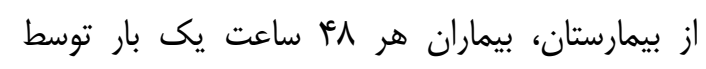

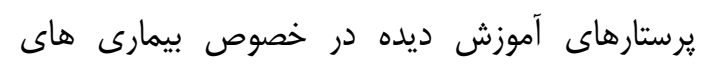

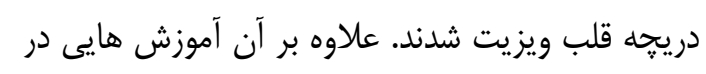
خصوص تكنيك هاى خودمراقبتى در هر مرحله از

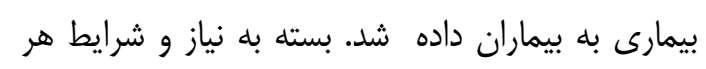

بيمار مدت زمان جلسات متفاوت بودان اين آموزش ها براى فردى كه بيشترين مسئوليت و ولسات منفاوت بود

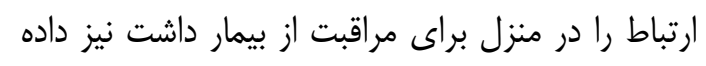
شد. يس از ترخيص نيز وضعيت بيماران از طريق

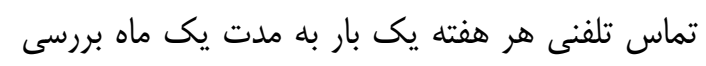

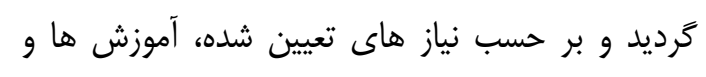
حمايت هاى لازم ارزيابى، تكميل و يا تعديل مى شد شد.

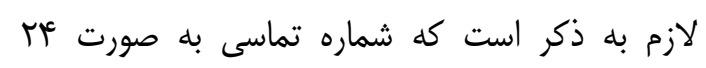

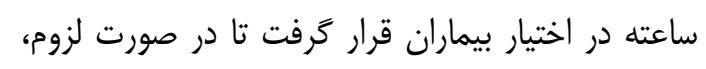

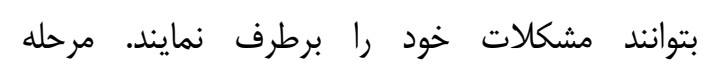

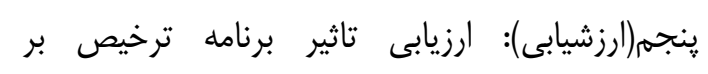

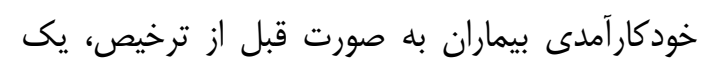

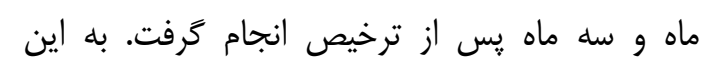

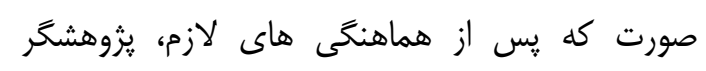

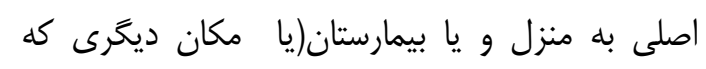

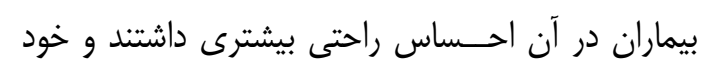

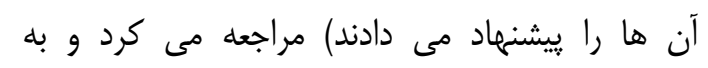
تكميل يرسش نامه ها مى يرداخت.
كنند. نمره كل اين يرسش نامه، بين كواته- است و

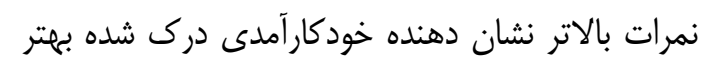

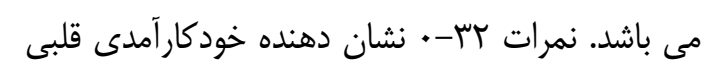

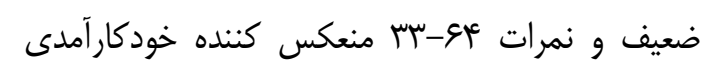
درى شده بالا مى باشد. اين يرسش نامه ابزارى معتبر

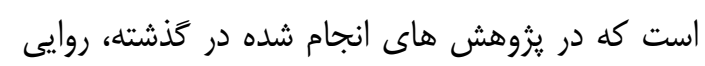

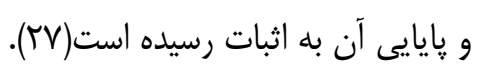

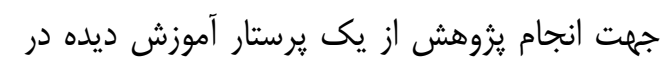

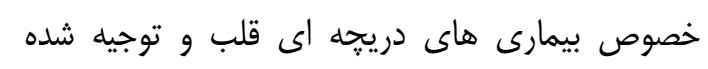

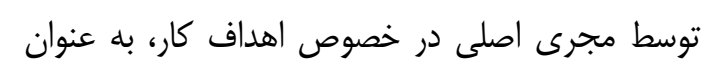

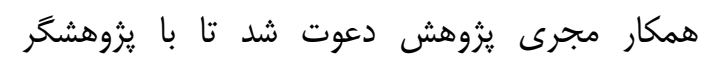

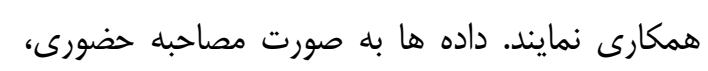

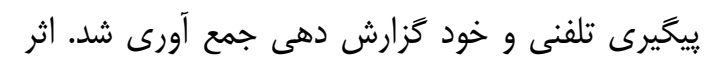

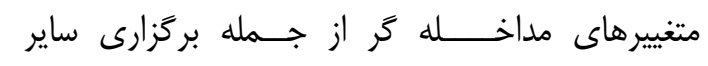
برنامه هاى آموزشى در بيمارستان، نيز بررسى ترديل

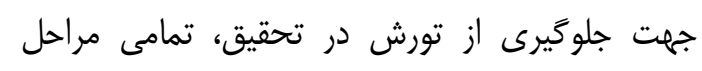

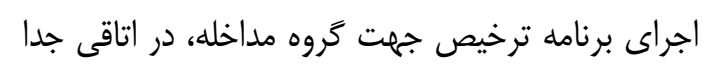

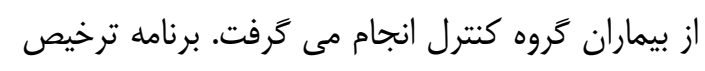

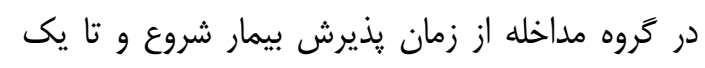

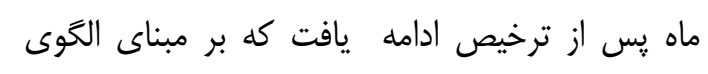

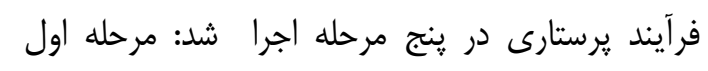

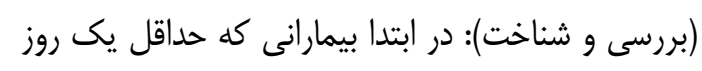

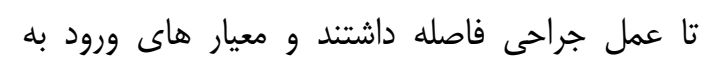

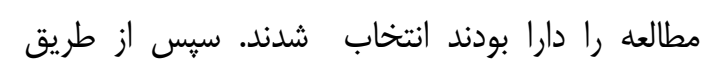
קك ليست محقق ساخته، بررسى يرونده، معاينه بيمار،

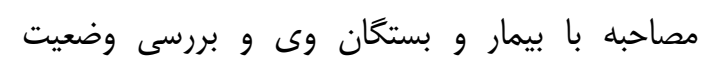

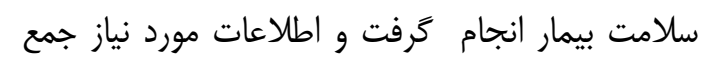

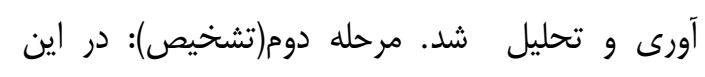

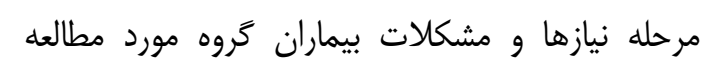
مشخص شد. مرحله سوم(برنامه ريزى برنامه ترخيص):

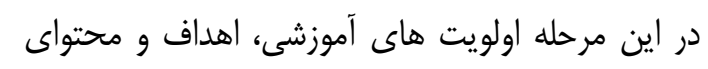

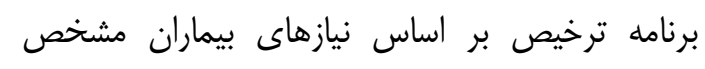
كرديد و بر همين اساس يكى كتابِه آموزشى تهبيه و تدوين شد(جدول شماره ()). جهت تعيين روايى محتوا،

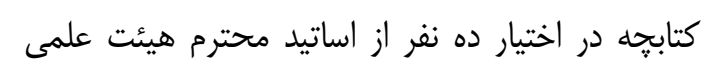

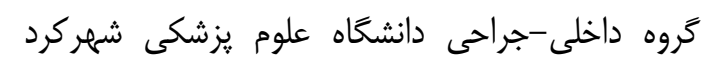




\begin{tabular}{|c|c|c|c|c|}
\hline \multicolumn{5}{|c|}{ جدول شماره ا. جُكَونَى اجراى برنامه ترخيص طراحى شده } \\
\hline شيوه تدريس & هدف & محتوا & زمان & شماره جلسه \\
\hline 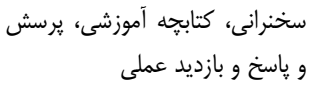 & ترس و اضطراب حس اعتماد در بيمار، كاهش & آشنايى با يرسنل و محيط بيمارستان & قبل از انتقال به اتاق عمل & 1 \\
\hline و پِاسخر & ترس و اضطراب آَاهى از روند درمان، كاهش & آشنايى با روند درمانى & قبل از انتقال به اتاق عمل & r \\
\hline 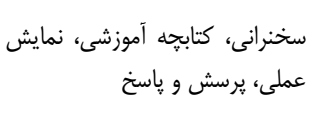 & كار آمديع ور روند بهبودى، اضطراب ايجاد حس خود & 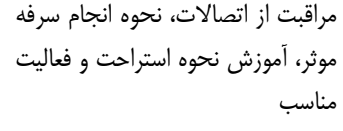 & بعد از انتقال به بخش & r \\
\hline 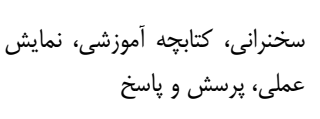 & كارآمديع، كاهش روند بهبودى، اضيجاد حس خود & مصرف وارفارين زمه، ملاحظات مربوط به & 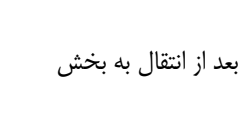 & r \\
\hline 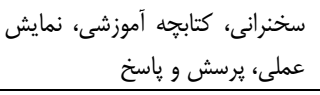 & 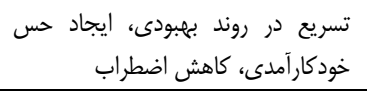 & ترخيص مديت مشكلات احتمالى پِ از & بعد از انتقال به بخش & $\Delta$ \\
\hline
\end{tabular}

از جمله سن، جنس، وضعيت تاهل، سطح تحصيلات و اشتغال را در دو گروه مداخله و كنترل نشان مى دهى دهد. همان طور كه اين جدول نشان مى دهد، متغيرهاى

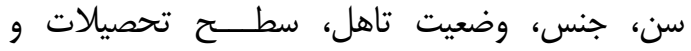

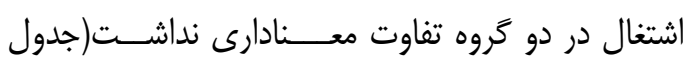

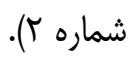

از آمار توصيفى و استنباطى با آزمون هاى كاى دو، من ويتنى، تى مستقل و آناليز واريانس و نرم افزار جهت تجزيه و تحليل داده ها استفاده شد.

\section{يافته هاى يزوهش}

جدول شماره r توزيع فراوانى نسبى و ميانگين واحدهاى مورد مطالعه برحسب مشخصات دموگرافيك تونى

جدول شماره r. توزيع فراوانى نسبى و ميانكَين واحدهاى مورد مطالعه برحسب مشخصات دموَّر افيك

\begin{tabular}{|c|c|c|c|c|}
\hline نوع آزمون & مداخله (ميانكَين $\mid$ مانحراف معيار) & كتترل (ميانكَين Iانحراف معيار) & 0,5 & متغير \\
\hline $\begin{array}{l}\mathrm{t} \text { independent } \\
\mathrm{P}=0.98\end{array}$ & $W / \Lambda \pm \Delta M / r F$ & $Q 1 \pm \Delta r / 19$ & \multicolumn{2}{|c|}{ سن } \\
\hline \multirow{2}{*}{$\begin{array}{c}\chi^{2} \\
\mathrm{P}=0.9\end{array}$} & ( & q/ع درصد & 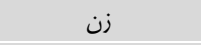 & \multirow[t]{2}{*}{ 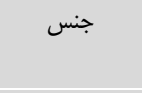 } \\
\hline & ه ه ه درصد & ا & مرد & \\
\hline \multirow{4}{*}{$\begin{array}{c}\chi^{2} \\
\mathrm{P}=0.57\end{array}$} & ل ب درصد & - & مجرد & \multirow{4}{*}{ وضعيت تاهل } \\
\hline & م N درصد & ع/ •9 درصد & 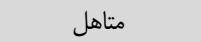 & \\
\hline & ل ب ل درصد & . & مطلقه & \\
\hline & درصد & 9/4 درصد & بيوه & \\
\hline \multirow{4}{*}{$\begin{array}{l}\text { من ويتنى } \\
\text { P=0. } 85\end{array}$} & 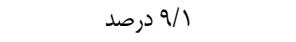 & 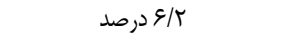 & بيسواد & \multirow{4}{*}{ سطح تحصيلات } \\
\hline & ه ه ه درصد & ج/ع درصد & فقط خواندن و نوشتن & \\
\hline & 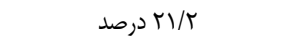 & ع/ F درصد & زير دييلم & \\
\hline & K/K/ درصد & 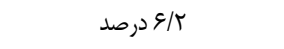 & دانشاهى & \\
\hline 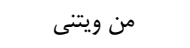 & 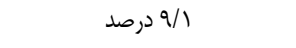 & 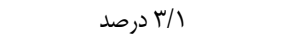 & 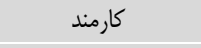 & \multirow{6}{*}{ وضعيت اشتغال } \\
\hline \multirow[t]{5}{*}{$\mathrm{P}=0.4$} & T & درصد & آزاد & \\
\hline & K/K/ درصد & ه م درصد & بازنشسته & \\
\hline & 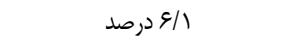 & ه/ ها درصد & كاركر & \\
\hline & F F F درصد & 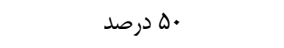 & خانه دار & \\
\hline & س بدرصد & - & دانشجو & \\
\hline
\end{tabular}

بيمارى زمينه اى را در دو كروه مداخله و كنترل نشان

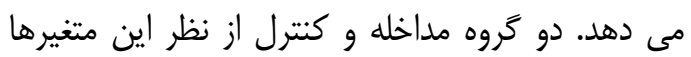
نيز تفاوت آمارى معنادارى نداشتند(جدول شماره بَ).
جدول شماره ب توزيع فراوانى نسبى واحدهاى مورد مطالعه بر حسب مشخصات بيمارى از جمله شدات نارسايى قلبى، مدت زمان ابتلا به بيمارى و داشتن 
جدول شماره س. توزيع فراوانى نسبى واحدهاى مورد مطالعه بر حسب داشتن بيمارى زمينه ایى

\begin{tabular}{|c|c|c|c|c|}
\hline نوع آزمون & مداخله & كنترل & 09,5 & متغير \\
\hline \multirow{3}{*}{$\begin{array}{l}\text { من ويتنى } \\
P>0.05\end{array}$} & ب درصد & • درصد & كلاس يك & \multirow{3}{*}{ شدت نارسايى قلبى } \\
\hline & ه/NF درصد & ع/. أ درصد & كلاس دو & \\
\hline & ه/NF درصد & ع & كلاس سه & \\
\hline \multirow{3}{*}{$\begin{array}{c}\chi^{2} \\
\mathrm{P}=0.57\end{array}$} & א/ או درصد & 1/N/ درصد & ا تا ه سال & \multirow{3}{*}{ مدت زمان ابتلا به بيمارى } \\
\hline & FT/F درصد & ع/. أ درصد & ه تا •ا سال & \\
\hline & ع/q درصد & ع/• أ درصد & بيش از •إل سال & \\
\hline \multirow{5}{*}{$\begin{array}{c}\chi^{2} \\
\mathrm{P}>0.05\end{array}$} & r/T درصد & Q/ ז درصد & ديابت & \multirow{5}{*}{ بتلا به بيمارى هاى زمينه اى } \\
\hline & ه/NF درصد & ه/ع درصد & فشارخون بالا & \\
\hline & آ ها درصد & ع/ q درصد & سكته قلبى & \\
\hline & ع/ • درصد & ه/א درصد & روماتيسم & \\
\hline & ף·/ף درصد & V// درصد & ساير & \\
\hline
\end{tabular}

تكرار مشاهدات(Repeated Measure) نشان داد كه

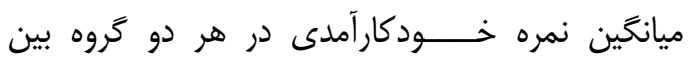
زمان هاى مختلف تفاوت معنادار داشت(

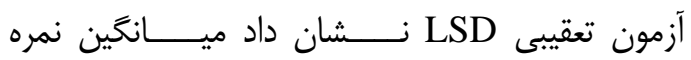

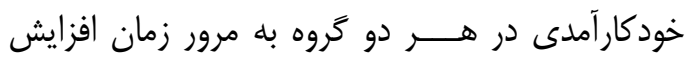

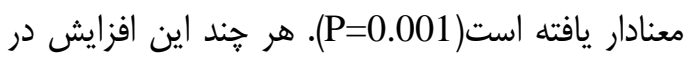

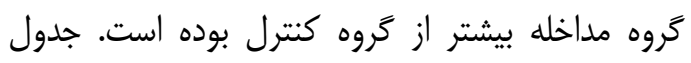

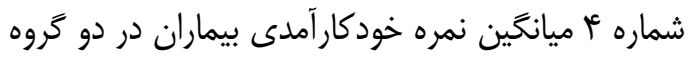

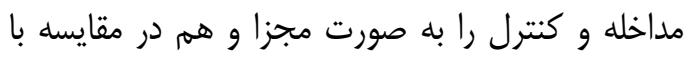
يكديخر نشان مى دهد.
همان طور كه در جدول شماره ع نشان داده شده

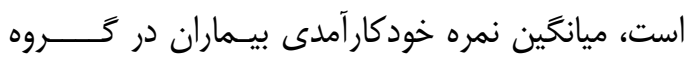

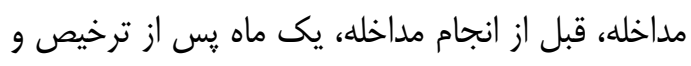

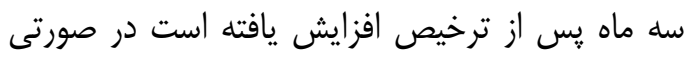
كه اين مقدار در كروه كنترل تغيير جندان زيادى نكرد إدها

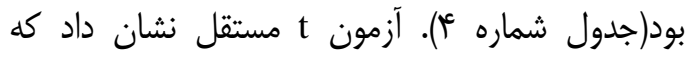

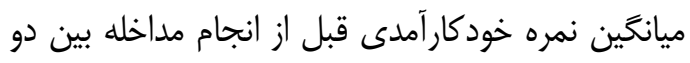

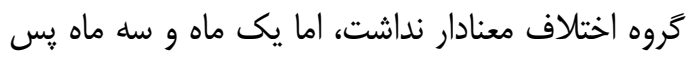
از ترخيص در كروه مداخله به طور معنادارى بيشتر از

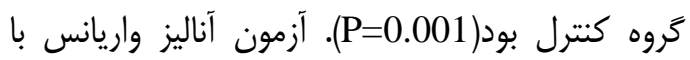

جدول شماره f. ميانكَين نمره خودكارآمدى بيماران در دو تروه مداخله و كنترل قبل، يك ماه و سه ماه يس از ترخيص

\begin{tabular}{|c|c|c|c|c|}
\hline \multicolumn{2}{|c|}{ آزمون t مستقل } & كروه كنترل & \multirow{2}{*}{$\begin{array}{l}\text { كروه مداخله } \\
\text { SD } \bar{X}\end{array}$} & \multirow[b]{2}{*}{ زمان } \\
\hline $\mathrm{P}$ & $\mathrm{T}$ & $\pm \mathrm{SD} \bar{X}$ & & \\
\hline$\cdot / \mu F$ &.$/ 9 V$ & $r F / \varepsilon \pm s / r^{c}$ & $r \kappa / q \cdot \pm r / q$ & قبل از مداخله \\
\hline$<\cdot / \cdot .1$ & $19 / \cdot 0$ & $r N / r \pm s / q$ & $r \varepsilon / \Delta V \pm r / q$ & يكى ماه پِ از ترخيص \\
\hline$<\cdot 1 \cdot . \cdot 1$ & $4) / \cdot q$ & $r r / q \pm V / F$ & $\Delta \mu / M \Lambda \pm r / \mu$ & سه ماه پس از ترخيص \\
\hline & & $F T / D F$ & $q 1 F / T V$ & آزمون آناليز واريانس با تكرار \\
\hline & & $<\cdot 1 \cdot+1$ & $<\cdot / \cdot+1$ & $\begin{array}{c}\text { مشاهدات } \\
\text { (Repeated Measure) }\end{array}$ \\
\hline
\end{tabular}

ميانخين در گروه مداخله به طور معنادارى بيشتر از

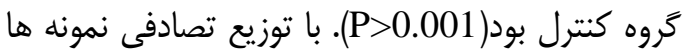

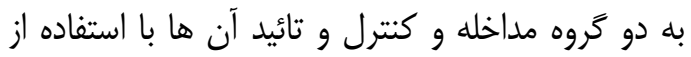

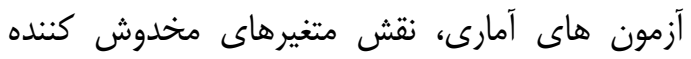

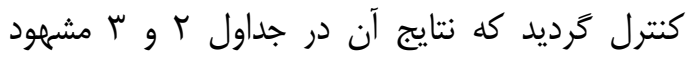

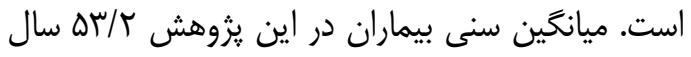
به دست آمد. در يك بررسى نيز كه توسط سميعى و

\section{بحث و نتيجه كَيرى}

در اين يزوهش اثربخشى برنامه ترخيص طراحى شده

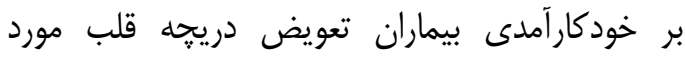
بررسى قرار گرفت. همان طور كه از نتايج اين مطالعه

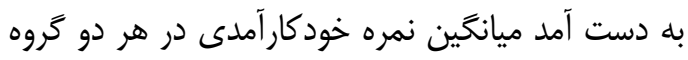

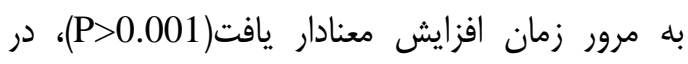
حالى كه يك ماه و سه ماه يس إز از ترخيص، اين 
جه كه واضح است تفاوت معنادار در سطح خودكارآمدى دو گروه است، كه مى تــــواند ناشــى از كيفيت

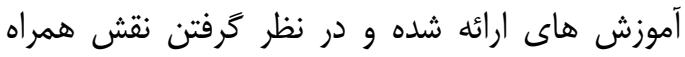

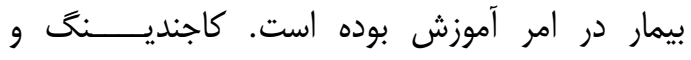

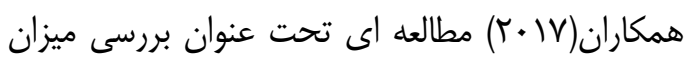
اثربخشى برنامه ترخيص ساختارمند با محوريت يرستار بر وضعيت خودكارآمدى بيماران سكته قلبى حاد انجام

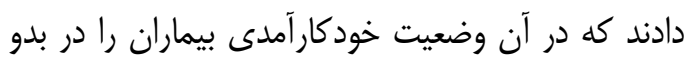

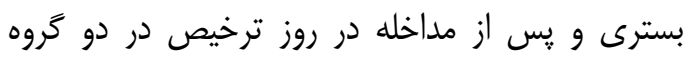

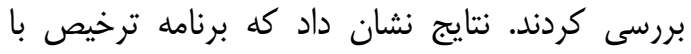
محوريت يرستار باعث بهبودى قابل توجه در سطح

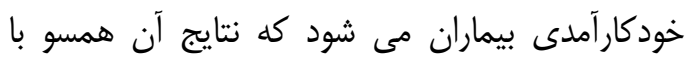
مطالعه حاضر است. هر جند اثربخشى آموزش هار هاى داده شده در اين مطالعه در دراز مدت بررسى نشده التها

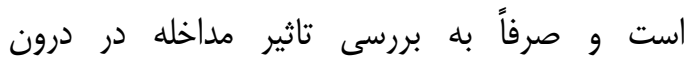

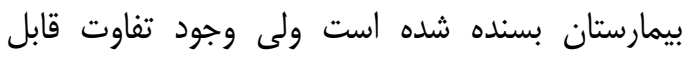
توجه در وضعيت خودكارآمدى بيماران در دو گروهات

بيانكَر كارا بودن برنامه ترخيص اجرا شده است(N)

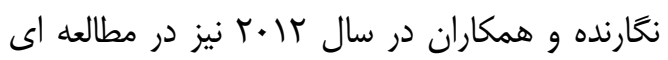

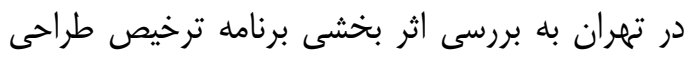

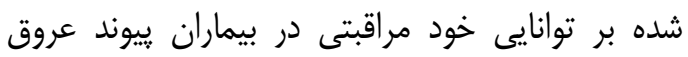
كرونر شش هفته و سه ماه بِ از ترخيص يرداخت و

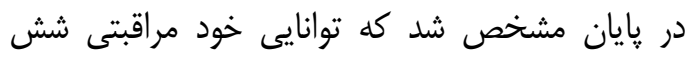

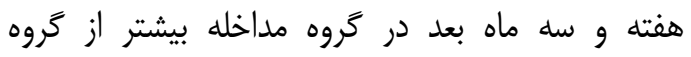

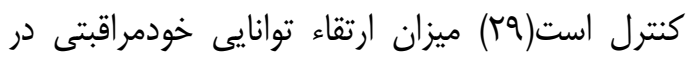

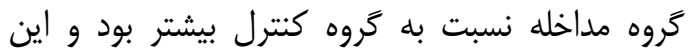

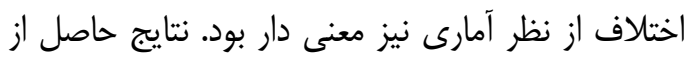

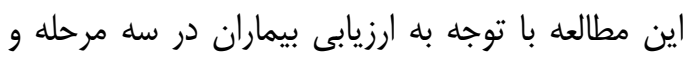

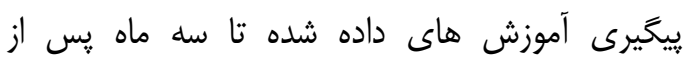
ترخيص تطابق زيادى با مطالعه حاضر دارد. عزيزى و همكاران در سال MMrا در مطالعه اي با بال هدف تعيين تاثير استراتزى هاى ارتقاء سلامت براري درى

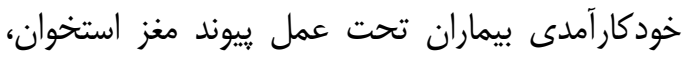

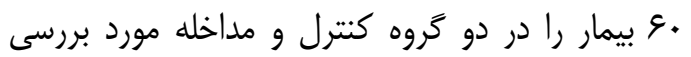

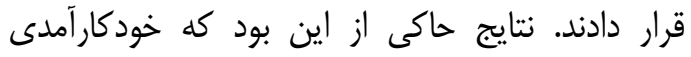

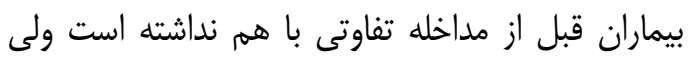

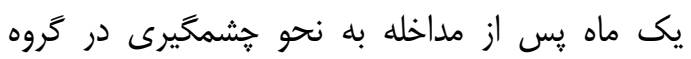
مداخله بيش از كروه كنترل بوده است(·ّ) نتايج حاصل
همكاران بر روى • I ا بيمار تعويض دريجه قلب انجام

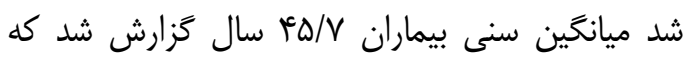

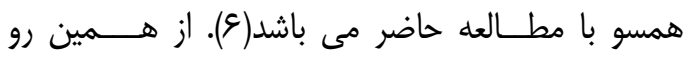

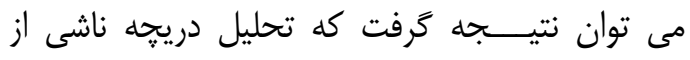

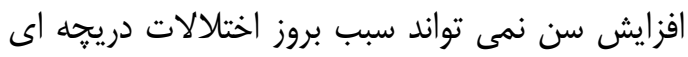

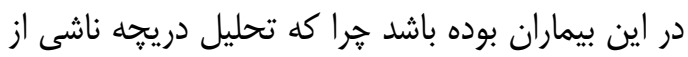

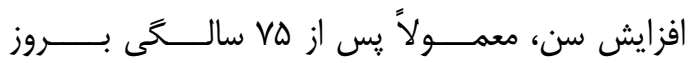
مى كند(ه).

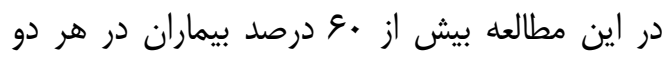
كروه سابقه ابتلا به روماتيسم قلبى را كزارش كرده اند، كه مى تواند دليلى بر بروز اختلالات دريجه ایى در اين رئل

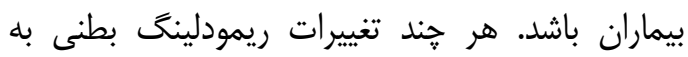
سبب فشار خون و سكته قلبى مى تواند سبب بروز

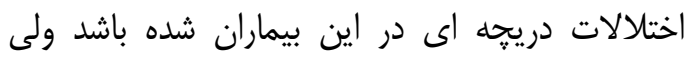

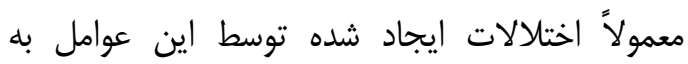
درمان يزشكى جواب مى دهند و در سنين بالاتر نياز به إنهاد

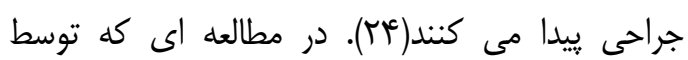

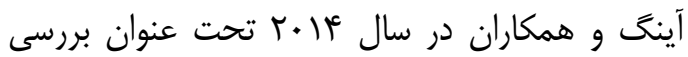
إيبدميولوزيك بيمارى هاى دريجه ائى در سطح دان جهان

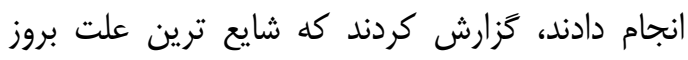

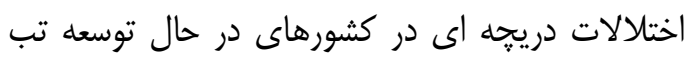

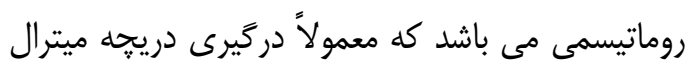
رابه دنبال دارد(ه).

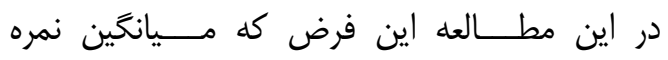

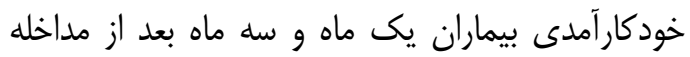

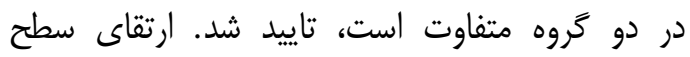

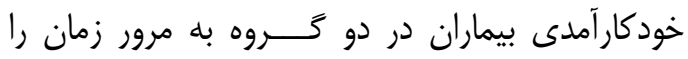
مى توان اين طور توضيح داد كه به طور طبيعى بيماران

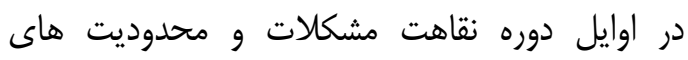
زيادى را در فعاليت، تغذيه، خواب و استراحت، رزيم غذايى و مراقبت از زخهم تجربه مى كنند كه به به مرور

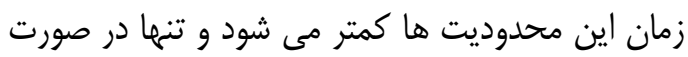
ايجاد عوارض جدى مى تواند بين بيشتر شده يا مدت زمان زمان طولانى ترى بيمار و خانواده را درگير كنند كه اين

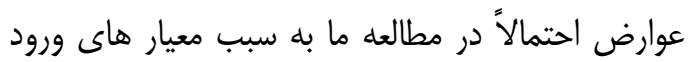
و خروجى كه لحاظ شد كمتر به وجود آمده است. هم

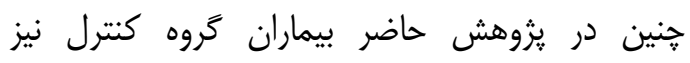

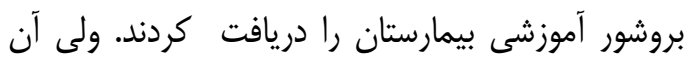


بيمار مى تواند امرى مهم در ارتقاى كيفيت مراقبت ها و كنترل هزينه هاى فردى و اجتماعى باشد.

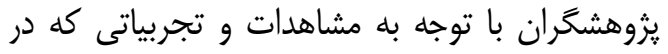

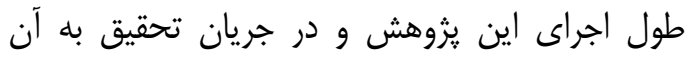
دست يافتند انجام يزوهش هايى در راستاى ارتقاى دري كيفيت مراقبت هاى يرستارى را ييشنهاد مى كنند؛ به إنها عنوان مثال با توجه با اين كه بيماران تعويض دريخها رئه قلب همواره در معرض عوارض ناشى از تعويض دريجه

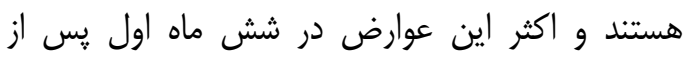
جراحى اتفاق مى افتد يِيشنهاد مى شود يزوهشى تحت

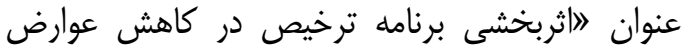

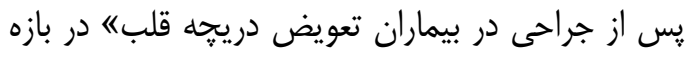

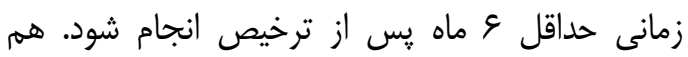

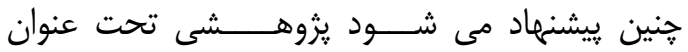
|اثربخشى برنامه ترخيص بر تبعيت از درمان بيماران تعويض دريجه قلبه سنجيده شود.

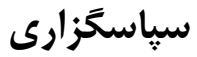

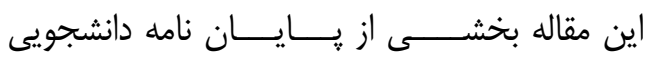

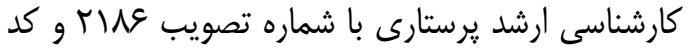

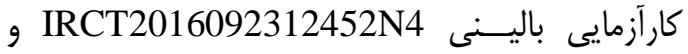
كد اخلاق IR.Skums.REC.1395.80 از از دانشعاه

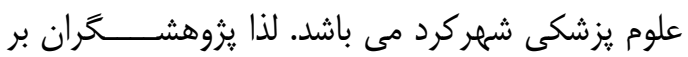

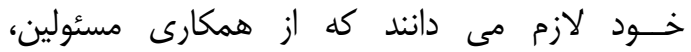
سريرستار، كادر بخش جراحى قلب و مراقــــــت هاى ويزه مركز آموزشى -درمانى شهيد جمران و و هم

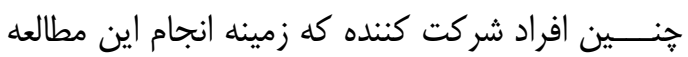

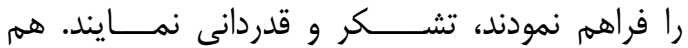

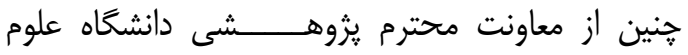

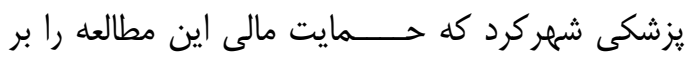

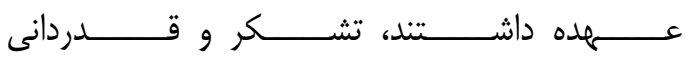

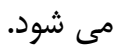

\section{References}

1.Mansour NB, Lassoued O, Saidi O, Aissi W, Ali SB, Romdhane HB. Trends in secondary prevention of coronary heart disease in Tunisia prevention of recurrences of MI and stroke. Glob Heart 2012;7:361-6. doi: 10.1016/j.gheart.2012.01.002.

2.Saadat S, Yousefifard M, Asady H, Jafari AM, Fayaz M, Hosseini M. [The most
از اين يزوهش نيز همسو با مطالعه حاضر است. هانگ

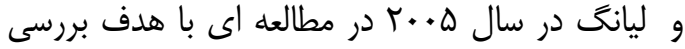
اثربخشى برنامه ترخيص در بيماران مسن با شكستكى

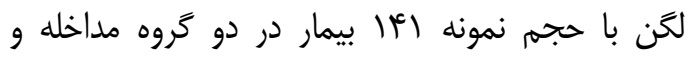
كنترل كزارش كردند كه فعاليت هاى خودمراقبتى بيماران قبل از مداخله و سه ماه پِ از ترخيص مورد بررسى قرار كرفت و در پايان مشخص شد كه اين

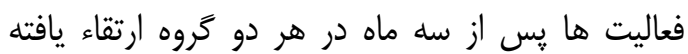
است ولى اين ارتقاء در خروه مداخله نسبت به كراه كنترل بيشتر بوده است(P<0.05) كه نتايج حاصل از آن همسو با مطالعه حاضر است(آ).

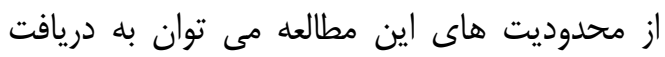

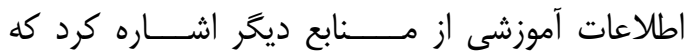

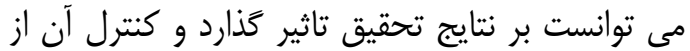

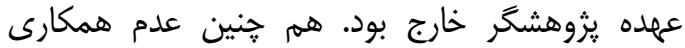

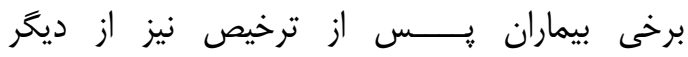
محدوديت هاى اين يزوهش بود.

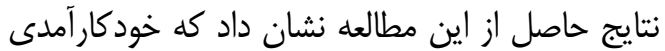
بيماران يك ماه و سه ماه يس از ترخيص در كروه

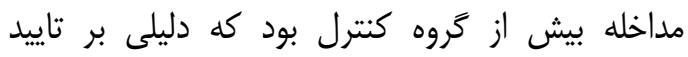

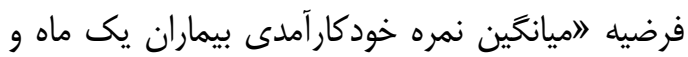

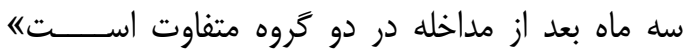
مى باشد و با اطمينان هو درصد مى توان كفت كه

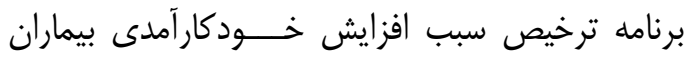
مى شود. با در نظر خرفتن نتايج اين مطالعه و با توجه به روند رو به رشد بيمارى هاى دريجه اى با توجه با دائ

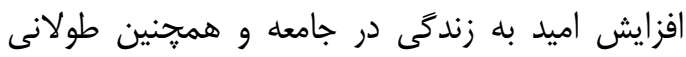
بودن دوره نقاهت اين بيماران و لزوم ايجاد تغييرات اجتناب نايذير در رزيم غذايى و سبك زندگى با توجه به مصرف وارفارين، ارائه مراقـــــبت هاى ويـــيـير و و برنامه ريزى شده بر اساس نياز هاى اختصاصى هر

important causes of death in Iranian population a retrospective cohort study]. Emergency 2015;3:16-17.(Persian)

3.Snowdon D, Haines TP, Skinner EH. Preoperative intervention reduces postoperative pulmonary complications but not length of stay in cardiac surgical patients a systematic review. J 
Physiother 2014;60:66-77.

doi:

10.1016/j.jphys.2014.04.002.

4.Schoen FJ. Heart valve tissue engineering: quo vadis? Curr Opin Biotechnol2011;22:698-705.

5.Iung B, Vahanian A. Epidemiology of acquired valvular heart disease. Can J Cardiol 2014;30:962-70. doi: 10.1016/j.cjca.2014.03.022.

6.Samiei N, Hakimi MR, Mirmesdagh Y, Peighambari MM, Alizadeh A, Hosseini S. Surgical outcomes of heart valves replacement a study of tertiary specialied cardiac center. Arya Atherosclero2014;10:233-7.

7.Linkova H, Petr R. Antithrombotic therapy in valvular heart disease and artificial valves. Cor Vas 2013;55: 158-63.

8.Amirabadi T, Nasiri A, Kazemi T, Kardan M. [Educational needs of patients with heart valve replacement surgery in Birjand, 2012]. Surg Trauma 2014;1:90-6. (Persian)

9.Berg SK, Zwisler AD, Pedersen BD, Haase K, Sibilitz KL. Patient experiences of recovery after heart valve replacement suffering weakness struggling to resume normality. BMC Nurs 2013 ;26;12:23. doi: 10.1186/1472-6955-12-23.

10.Taqaddosi M, Abdar Esfahani M, Musavi SGA. [Difficulties of patients with replaced heart valve in Kashan]. Feyz J 2005;9:62-9. (Persian)

11.Misawa Y. Valve related complications after mechanical heart valve implantation. Surg Today 2015;45:1205-9. doi: 10.1007/s00595-014-1104-0.

12. Kulik A, Rubens FD, Wells PS, Kearon C, Mesana TG, Berkom J, et al. Early postoperative anticoagulation after mechanical valve replacement a systematic review. Ann Thorac Surg 2006;81:770-81. 13. Meneses LST, Lima FET, Oliveira SKP, Oliveira FJG, Vieira M, Almeida PC, et al. Self care practice of patients with mechanical heart valve prosthesis accompanied in nursing consultation. Health 2015;7):1387-9.

14.Abedi H, Salimi SJ, Feizi A, Safari S. [Effect of self efficacy enhancement program on self-care behaviors in chronic obstructive pulmonary disease]. Iranian $\mathrm{J}$ Nurs Midwife Res 2013;18:421-3. (Persian) 15.Kang Y, Yang IS. Cardiac self efficacy and its predictors in patients with coronary artery diseases. J Clin Nurs 2013;22:246573. doi: 10.1111/jocn.12142.

16.Leahy P, Mccarthy G, Corcoran P. First time mothers social support maternal parental self efficacy and postnatal depression. J Clin Nurs 2012;21:388-97. doi: 10.1111/j.1365-2702.2011.03701.x.

17.Royani Z, Rayyani M, Vatanparast M, Mahdavifar M, Goleij J. [The relationship between self-care and self-efficacy with empowerment in patients undergoing hemodialysis]. Militar Car Sci 2015;1:11622. (Persian)

18.Brink E, Alsen P, Herlitz J, Kjellgren K, Cliffordson C. General self-efficacy and health related quality of life after myocardial infarction. Psychol Health Med 2012;17:346-55. doi: 10.1080/13548506.2011.608807.

19.Lin CJ, Cheng SJ, Shih SC, Chu CH, Tjung JJ. Discharge planning. Int $\mathbf{J}$ Gerontol 2012;6:237-40.

20.Nordmark S, Zingmark K, Lindberg I. Experiences and views of the discharge planning process among Swedish district nurses and home care organizers a qualitative study. HHCMP 2015;27:108-18. 21.Weiss ME, Yakusheva O, Bobay KL. Quality and cost analysis of nurse staffing discharge preparation, and postdischarge utilization. Health Serv Res 2011;46:147394. doi: 10.1111/j.1475-6773.2011.01267.x. 22.Zhu QM, Liu J, Hu HY, Wang S. Effectiveness of nurse led early discharge planning programmes for hospital inpatients with chronic disease or rehabilitation needs a systematic review and meta analysis. J Clin Nurs 2015;24:29933005. doi: 10.1111/jocn.12895.

23. Gholizadeh M, Delgoshaei B, Gorji HA, Torani S, Janati A. Challenges in patient discharge planning in the health system of Iran a qualitative study. Glob J Health Sci $2015 \quad$ 26;8:474-6. doi: 10.5539/gjhs.v8n6p168.

24.Nishimura RA, Otto CM, Bonow RO, Carabello BA, Erwin JP, Guyton RA, et al. 2014 AHA/ACC guideline for the management of patients with valvular heart disease a report of the American college of cardiology heart association task force on practice Guidelines. J Am Coll Cardiol 2017;70:252-89. doi: 10.1016/j.jacc.2017.03.011. 
25.Lancellotti P, Rosenhek R, Pibarot P, Iung $\mathrm{B}$, Otto $\mathrm{CM}$, Tornos $\mathrm{P}$, et al. ESC working group on valvular heart disease position paper heart valve clinics organization structure and experiences. Eur Heart J 2013;34:1597-606. doi: 10.1093/eurheartj/ehs443.

26.Sullivan MD, Lacroix AZ, Russo J, Katon WJ. Self efficacy and self reported functional status in coronary heart disease a six month prospective study. Psychosom Med1998; 60: 473-8.

27.Varaei S, Shamsizadeh M, Cheraghi MA, Talebi M, Dehghani A, Abbasi A. Effects of a peer education on cardiac self efficacy and readmissions in patients undergoing coronary artery bypass graft surgery a randomized controlled trial. Nurs Crit Care 2017;22:19-28. doi: 10.1111/nicc. 12118.

28.Cajanding RJ. Effects of a structured discharge planning program on perceived functional status cardiac self efficacy patient satisfaction and unexpected hospital revisits among filipino cardiac patients a randomized controlled study. J Cardiovasc Nurs 2017;32:67-77.

29.Negarandeh R, Nayeri ND, Shirani F, Janani L. The impact of discharge plan upon re admission satisfaction with nursing care and the ability to self care for coronary artery bypass graft surgery patients. Eur J Cardiovasc Nurs 2012;11:460-5. doi: 10.1016/j.ejcnurse.2011.05.001.

30.Azizifini I, Adibhajbaghery M, Salahshoorianfard A, Khachian A. [The effect of health promotion strategies education on self care self efficacy in patients with bone marrow transplantation]. J Crit Care Nurs2011;4:109-16. (Persian) 31.Huang TT, Liang SH. A randomized clinical trial of the effectiveness of a discharge planning intervention in hospitalized elders with hip fracture due to falling. J Clin Nurs 2005;14:1193-201. 


\title{
Effectiveness of a Proposed Discharge Plan on Self-Efficacy among Patients Underwent Cardiac Valve Replacement
}

\author{
Etemadifar $S^{l^{*}}$, Shafiei $E^{1}$, Masoudi $R^{1}$, Mirmohammadsadeghi $A^{2}$, Ahmadi $A^{3}$, Hadianjazi $Z^{4}$
}

(Received: June 2, 2019

\begin{abstract}
Introduction: A discharge plan is required to be included in the care plan of patients who underwent cardiac valve replacement surgery. Therefore, this study aimed to determine the efficacy of a proposed discharge plan on the self-efficacy of patients with cardiac valve replacement.
\end{abstract}

Materials \& Methods: This clinical trial study included 65 patients who underwent cardiac valve replacement at Shahid Chamran Hospital, Isfahan, Iran. The participants were then randomly assigned to intervention and control groups using a random allocation method. In the intervention group, the proposed discharge plan was implemented at the time of the patients' admission and continued one month after discharge based on a five-stage nursing process. The duration of hospitalization and the level of self-efficacy of patients before the intervention, one month, and three months after discharge in two groups were analyzed in SPSS software (version 22) through the Chi-square test, Mann-Whitney $\mathrm{U}$ test, independent t-test, and analysis of variance. Ethics code:
Accepted: November 2, 2019)

\author{
IR.Skums.REC.1395.80. Clinical Trial \\ Code: IRCT2016092312452N4
}

Findings: The mean score of self-efficacy increased significantly over time in the intervention (53.18 \pm 4.3$)$ and control groups (32.9 \pm 7.4$) \quad(\mathrm{P}=0.001)$. However, the intervention group obtained significantly higher self-efficacy scores after one and three months post-discharge, compared to the control group $(\mathrm{P}=0.001)$. Furthermore, according to the Least Significant Difference test, the most significant level of effect was after three months postdischarge.

Discussion \& Conclusions: The discharge plan as a method of providing ongoing care increases the level of self-efficacy of patients. Therefore, it is recommended that the discharge plan be used as an effective way to provide patients who underwent cardiac valve replacement with ongoing care.

Keywords: Discharge plan, Heart replacement, Self-efficacy

1. Dept of Medical Surgical, Faculty of Nursing and Mideifery, Shahrekord University of Medical Sciences, Shahrekord, Iran

2. Dept of Surgical, Faculty of Medicine, Isfahan University, Isfahan, Iran

3. Dept of Statistics and Epidemiology, Faculty of Public Health, Shahrekord University of Medical Sciences, Shahrekord, Iran

4. Dept of Medical Surgical, Faculty of Nursing and Mideifery, Iran University of Medical Sciences, Trhran, Iran

* Corresponding author Email: Etemadifar@nm.mui.ac.ir 